\title{
"Mobilising the community"
}

Modality and Ambiguities of HIV Carriers' Participation in China's Fight Against AIDS

Yuvany Gnep

\section{(2) OpenEdition}

\section{Journals}

Electronic version

URL: http://journals.openedition.org/chinaperspectives/4767

DOI: 10.4000/chinaperspectives.4767

ISSN: 1996-4617

\section{Publisher}

Centre d'étude français sur la Chine contemporaine

\section{Printed version}

Date of publication: 1 April 2009

Number of pages: 8-15

ISSN: 2070-3449

\section{Electronic reference}

Yuvany Gnep, «"Mobilising the community" », China Perspectives [Online], 2009/1 | 2009, Online since 01 April 2011, connection on 28 October 2019. URL : http://journals.openedition.org/ chinaperspectives/4767; DOI : 10.4000/chinaperspectives.4767 


\title{
"Mobilising the Community"
}

\author{
Modalities and Ambiguities of HIV Carriers' Participation in China's \\ Fight Against AIDS
} YUVANY GNEP

This article analyses the emergence of new forms of social mobilisation against HIV/AIDS in China. The central authorities' engagement and the opening to international aid have allowed people living with HIV/AIDS to take part in anti-AIDS activities. The imperatives of participative development and the history of anti-AIDS militancy stemming from a global dynamic favour HIV carriers' quest for a democratic say despite the semi-authoritarian context.

A s many international observers have noted in both academic works and in the media, the history of social response to HIV in China is marked by the central authorities' tardy acknowledgement of its existence. The famous UN report with the graphic title "HIV/AIDS: China's Titanic Peril" (I) revealed the magnitude and potential of the danger and the fear it generated worldwide. External pressure and local circumstances, which will be examined later, persuaded the government to begin fighting the "peril" from the start of the current decade. Foreign aid played a major role in China's fight against HIV/AIDS and supported the authorities in their plans to get a firmer grip on the epidemic. Now, while implementation of the programme is deemed more or less satisfactory, its theoretical content is clearly ambitious and in line with expectations. One of the main aims was fostering community participation, i.e., the inclusion of HIV carriers in the process of prevention and control.

Although this might seem obvious and logical, it is worth examining the significance of this objective as well as its repercussions locally. This article does not purport to assess the effectiveness and the level of application in practice of the community participation principle. In fact, the "community" notion lacks precision in the way it is used in the international development sector, as UN agencies that promoted the principle have themselves acknowledged. ${ }^{(2)}$ The aim is merely to discern some of the ideological articulations implied by the principle's implementation by illustrating its use by activists and in associated activities involving the participation of Chinese HIV carriers. ${ }^{(3)}$

In the first section, the main characteristics of the epidemic in China will be explained so as to set the social context from which community initiatives have emerged. The next dwells on the major lines of official and public response and presents the main figures involved in AIDS activism in China, including HIV-positive individuals. The final section looks at the issue of representativity through the example of the process to select community-based members for the Chinese office of the Global Fund to fight AIDS, Tuberculosis and Malaria.

\section{Epidemics: Transmissions routes and their connotations}

According to official estimates, which are subject to regular review by international aid experts, ${ }^{(4)}$ people living with HIV/AIDS number about 700,000 in China today, ${ }^{(5)}$ with around 40,000 deaths attributed to AIDS. About 35,000 people receive antiretroviral treatment, with about 190,000 estimated to need it. These figures hide contrasting realities, which will be described to provide a fuller picture of the HIV epidemic in China.

1. United Nations Theme Group on HIV/AIDS in China, "HIV/AIDS: China's Titanic Peril. 2001 Update of the AIDS situation and Needs Assessment Report," Beijing, UNAIDS, 2001 http://www.youandaids.org/unfiles/chinastitanicperillast.pdf (All websites last visited by the author on 12 December 2008)

2. A UNAIDS guide explains that it "defines 'community' in its widest and most inclusive sense: a community is a group of people who have something in common and will act together in their common interest." Community mobilisation and AIDS, UNAIDS technical update, April 1997,

http://data.unaids.org/Publications/IRC-pub03/CommMob-TU_en.pdf

3. This article is based on fieldwork done in $2006 / 2007$ as part of doctoral studies in anthropology, under the direction of Evelyne Micollier and co-direction of Alice Desclaux of the Universite Paul Cézanne, Aix-Marseille 3, and the guidance in China of Pan Suiming of the Renmin University of China in Beijing. The study benefited from financial support as part of the IRD/PUMC-CAMS research programme "Social responses, impact of gender and mobilisation of scientific/traditional knowledge in the framework of dealing with HIV/AIDS in China," coordinated by E. Micollier, IRD (UMR 145), and Liao Susu, PUMC/CAMS, Beijing. CEFC, Hong Kong, made funding contribution to the programme in 2006. 


\section{Initial waves: Rural provinces and transmission through blood}

The main characteristic of the appearance of HIV in China lies in the primacy of the intravenous transmission mode, which distinguishes it from other epidemics. The very first places where it spread, in the late 1980s, were border regions in the south and northwest such as Yunnan, Guangxi, Guangdong, and Xinjiang. The infection there was mainly due to the sharing of syringes and drug use. Most of these provinces are also among the poorest in China, and the affected populations in the remote parts of these regions are also among the most disadvantaged. Consequently, the first epidemic wave reinforced the "foreignness" often associated with HIV/AIDS. ${ }^{(6)}$ At the national level, the authorities contented themselves with finger-pointing at foreigners, and in the provinces it was the lot of ethnic minorities to be the target of such prejudice. ${ }^{(7)}$

In the mid 1990s, too, a mainly rural and impoverished population became a major victim of HIV, but this time the location was a central province, Henan. Extensive and mercenary blood donation programmes lay behind massive contamination there. ${ }^{(8)}$ Lack of oversight over products and reinjection of other donors' blood after plasma extraction had spectacularly catastrophic consequences, such as high infection rates in areas now dubbed "AIDS villages" (aizibingcun). Local authorities who were roundly blamed for the epidemic refused to even acknowledge it. Their eventual implication in the disaster fuelled debate and a spirit of revolt among the affected people, taken up by activists from urban areas and informed by a globalised vision.

The image of an HIV-positive person as being from a rural area, a poor farmer, belonging to an ethnic minority, and a drug addict to boot, is the dominant one in China, especially in prevention messages. Even though contamination modes are changing and now increasingly affect urban areas, this image reflects a certain reality, as in late 2005 UNAIDS estimated that some 55 percent of known HIV/AIDS cases were either drug addicts (44 percent) or resulted from blood donation or transfusion (10.7 percent).

\section{Transmission through sex and urbanization of the epidemic}

Transmission through the sexual route is increasingly evident in major cities such as Guangzhou, Shanghai, and Beijing. As in other countries, sex workers are the most vulnerable group, ${ }^{(9)}$ as well as men in homosexual relationships
$(\mathrm{MSM}),{ }^{(10)}$ given the clandestine and stigmatised nature of these two groups and/or their practices.

In referring to the MSM group, this article follows the label not only because it is part of the jargon used by the international aid community, but also because it reflects the local reality better than the term "homosexual." In fact, the identity crisis that gays and lesbians in the West passed through in the 1950s and 1960s ${ }^{(1)}$ has been echoed in China to only an limited degree among those calling themselves "comrades" (tongzhi), ${ }^{(12)}$ a term popularised by Hong Kong's MSM community. The decriminalisation of homosexual practices came about only as recently as 1997 , and homosexuality was not removed from the official list of mental disorders until 2001. The absence of a sufficiently rooted "homosexual culture" and of identification or feeling of belonging to a homosexual community explains why an estimated 80 to 90 percent of China's MSM are married. ${ }^{(13)}$ It is the most acceptable solution for most of the MSM population, who can thus fulfil filial duty and live with their sexuality while respecting the central social institution, namely the family. However, despite the invisibility of the great majority of the MSM population, a tongzhi community has emerged in urban areas. Influenced by the global homosexual culture, they have invested in the fight against HIV/AIDS, using it

4. Therese Hesketh, 2007, "HIV/AIDS in China: The numbers problem," The Lancet, V. 3699562, pp. 621-623

5. UNAIDS, 2008, Report on the Global Epidemic, http://www.unaids.org/en/Knowledge Centre/HIVData/GlobalReport/2008/2008_Global_report.asp

6. For China's case, see Evelyne Micollier, "L'autre: Porteur originel et/ou vecteur du $\mathrm{VIH} /$ sida Chine populaire - Taiwan" (The other: original carrier and/or vector of HIV/AIDS [China-Taiwan]), Autrepart, n. 12: Le SIDA des autres (0thers' AIDS), 1999, pp. 73-86.

7. As described, for example, by Sandra Hyde following interviews with cadres in southwestern provinces: S. Hyde, Eating Spring Rice: The Cultural Politics of AIDS in Southwest China, Berkeley, University of California Press, 2007.

8. See Pierre Haski, Le sang de la Chine: Quand le silence tue (China's blood: When silence kills), Paris, Grasset et Fasquelle, 2005; and for an anthropological analysis of the blood donation trade and its effects on the spread of HIV in Henan: Ann Anagnost, "Strange Circulations: The Blood Economy in Rural China," Economy and Society, 2006, n. 35-4, pp. 509-529.

9. Pan Suiming, Red Light District: Exploration of Sex Work in China (Cunzai yu huangmi: Zhongguo dixia "xingchanye" kaocha), Beijing, Qunyan, 1999, Huang Yingying et al., "HIV/AIDS Risk among Brothel Based Female Sex Workers in China. Assessing the Terms, Knowledge and Content of Sex Work," Sexually Transmitted Diseases, n. 31, 2004, pp. 695-700.

10. "Men who have sex with men." On their vulnerability in the Chinese context, see Pan Suiming, "Male Homosexual Behavior and HIV-related Risk in China," in Aggleton, Peter (ed), Bisexuality and AIDS: International Perspectives, London, Taylor-Francis, coll., "Social Aspects of Aids," 1996

11. See Marche, Guillaume, "Le mouvement gai et lesbien américain face au SIDA" (American gay and lesbian movement confront AIDS), I'Homme et la société, n. 143-144, 2002, pp. 185-201.

12. Chou Wah-Shan, "Homosexuality and the Cultural Politics of Tongzhi in Chinese Societies," in Gerard Sullivan and Peter A. Jackson (eds), Gay and Lesbian Asia: Culture, Identity, Community, New York, Haworth, 2001.

13. Pan Suiming, op cit. 
to contact other individuals and encourage them to be open about their sexual orientation. Meanwhile, "homosexual deviance" in the national imagination had foreign, especially Western origins, ${ }^{(14)}$ and this was reinforced by the rise of the HIV epidemic.

Despite a growing profile, the role of MSM activists in the fight against HIV/AIDS is for now far removed from the pioneering work of homosexuals in the West. ${ }^{(15)}$ Before examining the circumstances under which the first MSM activists emerged, it would be appropriate to trace the salient lines of social response in the face of HIV/AIDS and the first activists in China.

\section{Official and public responses}

\section{Governmental and non-governmental responses}

In the 1990s, Chinese official response centred on prevention. A reluctance to recognize the epidemic's magnitude has frustrated implementation of any therapeutic or social programme for HIV carriers. While the government's failure to take direct action in the initially infected regions led to a certain tolerance of NGO help for HIV carriers in southern China, the scandal linked to blood transfusion in Henan in the late 1990s only hardened the official policy of denial. In 2003, the SARS scare ${ }^{(16)}$ made the central authorities realise the imminent dangers presented by epidemics. On World AIDS Day, 1 December 2003, Premier Wen Jiabao and then vice-premier Wu Yi visited Ditan Hospital in Beijing, gripped the hands of HIV carriers and solemnly announced the policy of "Four Frees and One Care." (17) This public health policy includes free ARV treatment for patients in rural areas and those in cities who lack the means, free voluntary counselling and testing, free prevention methods for mother-to-child transmission, free schooling for AIDS orphans, and provision of social relief for HIV patients. The National Centre for AIDS/STD Control and Prevention is in charge of implementing this policy. Such official engagement facilitated the efforts of international agencies and $\mathrm{NGOs}$ relating to HIV/AIDS in China. As a result, following a UNAIDS refusal to fund China in 2002 due to the severe lack of transparency, China's funding proposal for HIV/AIDS was accepted in late 2003.

As for civil society, which has been much talked about in social science literature, ${ }^{(18)}$ it is worth noting the special place of GONGOs, ${ }^{(19)}$ which bridge the official and pub- lic domains. Operating largely under state oversight, they carry out their activities in the social domain and are registered with the Civil Affairs Ministry. Their members are mostly retired officials. In theory, all other associations have to function under the aegis of one of these GONGOs in order to apply for state recognition. The problem of official registration for associations that have emerged in the NGO sector reveals the ambiguity of their place in China. Their autonomy is curbed by the informality with which they are obliged to act. Thus local NGOs, also called "grassroots organisations" (caogen zuzhi), a term often used in the HIV/AIDS sector for community organisations (shequ zuzhi), are obliged to juggle the discretion imposed by the tenuousness of their status and the visibility imparted by their appeals for funds. Despite its nascent and precarious nature, Chinese civil society is playing an increasingly major role, and is leaving a mark on political life that the state cannot ignore. ${ }^{(20)}$ Although this also implies an evolution of Chinese citizenship, ${ }^{(21)}$ literature on the subject tends to act as a damper on international actors, who tend to see democracy as the logical outcome of an opening to capitalism or to the outside world. After the Sichuan earthquake in May 2008, for example, humanitarian rhetoric was kept in harmony with national ideology.

14. For the Republican period, see Frank Dikötter, Sex, Culture and Modernity in China Medical Science and the Construction of Sexual Identities in the Early Republican Period London, Hurst, 1995; and on sexuality in China in relation to AIDS: E. Micollier, "AIDS in China: Discourses on Sexuality and Sexual Practices - The state's management of the epidemic both reflects and illuminates social contradictions," China Perspectives, JulyAugust 2005, http://www.cefc.com.hk/pccpa.php?aid=2006.

15. Christophe Broqua, France Lert, Yves Souteyrand, (eds), Homosexualités au temps du sida: tensions sociales et identitaires (Homosexuality in the time of AIDS: social and identity tensions), Paris, ANRS, Coll. "Collection Sciences sociales et sida" (Social Sciences Collection and AIDS), 2003.

16. Severe acute respiratory syndrome.

17. In Chinese "Simianyiguanhuai," see State Council Working Committee Office, United Nations theme Group on HIV/AIDS in China , A joint assessment of HIV/AIDS prevention, treatment and care in China, 2004

http://www.chinaids.org.cn/n443289/n443295/n447114/5206. On the context in which this policy emerged, see Joan Kaufman, Arthur Kleinman, Tony Saich, (eds), AIDS and Social Policy in China, Cambridge, Harvard University Press, 2006

18. On the reconsideration of the enthusiasm surrounding the emergence of this space in Chinese society, see Philip C. Huang, "'Public Sphere'/'Civil Society' in China? The Third Realm Between State and Society," Modern China, n. 19, 1993, pp. 216-240; Gordon White, Jude A. Howell, Shan Xiaoyuan (eds), In Search of Civil Society: Market Reform and Social Change in Contemporary China, Clarendon Press, Oxford, 1996; Michae Keane, "Broadcasting Policy, Creative Compliance and the Myth of Civil Society," Media Culture \& Society, n. 23-6, 2001, pp. 783-798.

19. Government organised/operated non-governmental organisations.

20. Peter Ho, "Embedded Activism and Political Change in a Semiauthoritarian Context," China Information, Vol. 21-2, 2001, pp. 187-209.

21. Merle Goldman and Elizabeth J. Perry (eds), Changing Meanings of Citizenship in Modern China, Cambridge, Harvard, University Press, 2002. 
were responding to a different model. The best known is gynaecologist $\mathrm{Gao}$ Yaojie, a winner of numerous international honours, who began directly helping people affected by HIV/AIDS in Henan in the mid-1990s. The authorities still regard her activity with suspicion, as evidenced by the frequent harassment, including house arrest, to which she has been subjected. However, given her status as a physician and the sympathy she inspires among the public at large for the conformist nature of her engagement, she has been spared more direct repression and has even gained some official recognition. ${ }^{(28)}$ She is not alone. There are others such as doctor Zhang $\mathrm{Ke}$, who has also travelled widely in Henan and founded the association Sunshine Doctors (yangguang yisheng), or doctor Xu Lianzhi ${ }^{(29)}$ of the Beijing You'An Hospital, who inspired the setting up of an organisation named Home of Loving Care (aixin jiayuan) in the infectious diseases department where she works. These activists' feeble or even nonexistent opposition to the government, despite associating themselves with some demands, ${ }^{(30)}$ explains the minimum disturbance they have suffered in their work and engagement. Home of Loving Care has even received official backing from the GONGO Chinese Association for HIV/AIDS and STD Prevention and Control since 1999.

At the other end of the doctor-patient equation, HIV carriers had initially been most discreet, and until 2003 had no presence except in their passive role as patients. The reasons for this discretion are quite simple, given their situation first of all as people carrying an epidemic stigma, with geographic, economic, and symbolic marginalisation ${ }^{(31)}$ compounding the lack of concern for their lot. In fact, the first person in China who openly identified himself as HIV-positive, Song Pengfei, does not conform to the typical characteristics of this population. He was 17 years old when infected through a blood transfusion in 1998. With his parents' backing he alerted local and international media, ${ }^{(32)}$ and soon emerged as the "representative" of Chinese HIV carriers in international conferences. ${ }^{(3)} \mathrm{He}$ had the opportunity to shake hands with then-President Bill Clinton in 2004 during the 15th International AIDS Conference in Bangkok. ${ }^{\left({ }^{44}\right)} \mathrm{His}$ "victim" status was not in doubt, given his age and the obvious reason for his infection. The responsibility of the hospital that carried out the transfusions was clearly set out and recognised in a case his family filed and won. Some years earlier he had begun clandestinely organising meetings and improvising psychological support for HIV carriers in Beijing.

Li Xiang (or Adam Li) in 2001 became the second person to openly declare himself HIV-positive. He, too, was infect- ed through a transfusion when he was a student. As he did not belong to the "traditional" vulnerable categories infected by HIV in China, he likewise carried no stigma. Li became one of the first people to represent HIV carriers in the Global Fund in 2003. Like Song, he enjoyed a highly positive image in the AIDS field, including among HIV carriers, who readily cite both and invariably praise their "bravery" (yonggan) and even their heroism (yingyong). ${ }^{(35)}$ Thomas Cai is another noted HIV-positive activist who came out quite early, but under a pseudonym. After he was diagnosed positive in 2000, he formed his mutual aid association Aids Care (ai zhi guanhuai) in Guangzhou. The situation of being from a coastal province and the connotations associated with the epidemic in southern China might explain his recourse to a pseudonym. At the same time, his contacts with the international aid milieu, helped by many foreign trips and his knowledge of English, propelled him as a representative of HIV carriers alongside Li Xiang in several structures, especially the International Treatment Preparedness Coalition (ITPC), ${ }^{(36)}$ Clobal network for positive people (GPN+), ${ }^{(37)}$ and the Global Fund.

Generally speaking, there were few HIV carriers among activists before quality ARV treatment was made freely available. As in most countries, access to medication led to a massive mobilisation of HIV carriers, and in China's case, as in other developing countries, the mobilisation met a requirement set by developed countries funding the fight against HIV/AIDS. This double phenomenon can be illus-

28. Micollier, "Acteurs de la mobilisation collective contre le sida en Chine et solidarités transnationales: dynamiques locales et visibilité des groupes de défense des minorités sexuelles et sociales" (Actors in China's anti-AIDS mobilisation and transnational solidarity: Local dynamics and visibility of groups defending gender and social minorities), Face à Face. Regards sur la santé, no. 7, 2005, pp. 31-40, http://www.ssd.ubordeaux2.fr/faf/archives/numero_7/articles/micollier.htm.

29. Meng Lin refers to the physician in the text published in this number.

30. See for instance the report on the situation in Henan by doctor Zhang Ke: Henan aizibing wunian diaocha baogao (Report on AIDS in Henan after five years of investigations), 2005 ,

http://www.ngocn.org/?action-viewnews-itemid-2607.

31. On the marginalisation phenomenon, see Yanqiu Rachel Zhou, "If you get AIDS? You have to endure it alone': Understanding the social constructions of HIV/AIDS in China," Social Science \& Medicine, Vol. 65-2, 2007, pp. 284-295.

32. Elisabeth Rosenthal, "Health System in China Fails as AIDS Enters," New York Times, 10 March 1999, http://query.nytimes.com/gst/fullpage.html?res=9B05E5D71E3FF933A 25750C0A96F958260\&sec=health\&spon=\&pagewanted=print.

33. Jennifer Hyman, "Song Pengfei's road from victim to advocate," Global AIDSLink, n. 79, 2003.

34. "NGOs active in China's fight against AIDS," China Daily, 20 July 2004, http://www.chinadaily.com.cn/english/doc/2004-07/20/content_350043.htm.

35. In public comments and private interviews.

36. http://www.hivcollaborativefund.org/index.php?id=117.

37. www.gnpplus.net. 
trated through the selection process for HIV carrier representatives in the Global Fund and the tensions it provoked in the community.

\section{The representation issue}

\section{Global dynamics and local echoes}

The demand for representation of HIV carriers in the fight against HIV/AIDS, which was seen in developed countries right from the start, has been the subject of many descriptions highlighting the new role of affected people as one of the main social innovations resulting from the HIV epidemic. ${ }^{(38)}$ This demand led to the questioning of biomedical authority in the doctor-patient relationship and also in the field of research. ${ }^{(39)}$ Internationally, patients rights associations from developed countries have weighed in at the major agencies engaged in HIV/AIDS work such as UNAIDS and the Global Fund. ${ }^{(40)}$ These agencies seek to apply the policy in countries where they intervene by including HIV carrier representatives. From the outset, the presence of these representatives showed an overarching logic going beyond access to treatment and tending towards a particular mode of governance in which the democratic objective is attached to health assistance. Such deterritorialisation of sovereignty ${ }^{(4)}$ and the paradoxes it can lead to locally are easily discernible in China, where international organisms sometimes signal quite openly their wish to influence the local political context and contribute to democratising the country.

In this regard, the many vagaries of the Country Coordination Mechanism $(\mathrm{CCM})^{(42)}$ are revealing, as they show the tensions entailed in the emergence of the associative sector in the anti-HIV/AIDS camp. In 2002, China became one of the first countries to set its CCM proper terms of reference, thus showing its credentials to accept the responsibility of making proposals to the Global Fund. However, the clauses put in were not too clear with regard to the CCM's composition, and this had to be remedied three years later when the acceptance of China's proposal at the third round of the Global Fund led to a surge in the number of organisations seeking to take part in the committee. ${ }^{(4)}$ The $\$ 90$ million allocated made for a strong argument to adopt adequate provisions for civil society participation in the Fund's policies. China sought to restrict access to the $\mathrm{CCM}$ and to rationalise its composition by balancing the different sectors represented (official, private, community, etc.). This strategy required recourse to an external commis- sion charged with evaluating conflicting demands and formulating a new text stipulating the number of representatives from each sector. ${ }^{(44)}$

Following this new text, an election was held behind closed doors in April 2006. However, the election was announced hurriedly and with little publicity. Only 14 community-based organisations and seven HIV carriers were present at the meeting where the vote was taken. Thomas $C$ ai was elected representative of HIV carriers. Soon thereafter, his election and those of the community-based organisations were criticised by Wan Yanhai, who alleged manipulation. ${ }^{(4)}$ Open conflict ensued among different groups, ${ }^{(4)}$ notably between Wan and government members of the CCM. $\mathrm{He}$ denounced their authoritarian methods, and they in turn attacked him for lacking patriotism and of acting at the behest of "foreigners" (wei waiguoren fuwu). ${ }^{(4)}$ These exchanges, albeit between parties at two extremes, are characteristic of a recurrence of opposing poles in the strategies of actors over collaboration with state organs. For example, the representative chosen on behalf of community-based organisations, the lawyer Jia Ping, had earlier been a member of Wan's Aizhixing, from which he resigned over differ-

38. Among others, Steven Epstein, La Grande révolte des malades: Histoire du sida, tome 2 Paris, Le Seuil/Les Empêcheurs de penser en rond, 2001; Janine Barbot, Les Malades en mouvements. La médecine et la science à l'épreuve du sida, Paris, Balland, 2002, Patrice Pinell, (ed), Une épidémie politique. La lutte contre le sida en France (19811996), Presses universitaires de France, coll. "Science, histoire et société," Paris, 2002.

39. François Buton has synthesized epistemological questions in the research on the subject: Francois Buton, "Sida et politique: saisir les formes de la lutte" (AIDS and politics: gauging the forms of the battle), Revue française de sciences politiques (French Review of Political Sciences), Vol. 55-5, 2005, pp. 787-810,

http://www.cairn.be/load_pdf.php?ID_ARTICLE=RFSP_555 0787

40. For a problematisation of their participation in regulating health governance globally, see Marc Dixneuf, "La santé, enjeux de gouvernance mondiale?", Cahiers d'Etudes du CERI, no. 99, December 2003, http://www.ceri-sciences-po.org/publica/etude/etude99.pdf.

41. See the "migrant sovereignty" concept illustrated by many humanitarian contexts in Marc Abelès (ed), Politiques jeux d'espaces, Anthropologie et Sociétés, no. 26-1, 2002, and this article on its application in the AIDS field: Nguyen Vinh-Kim, "Sida, ONG, et la politique du témoignage en Afrique de l'ouest," Anthropologie et Sociétés n. 26, 2002, pp. 69-87.

42. The mechanism exists in all countries where the Global Fund is active. Its governing principles can be read here: http://www.theglobalfund.org/documents/ccm.

43. See the history of the reform in terms of references and their antecedents: China Global Fund CCM, Briefing on China CCM Reform and Members Selection, 2005, http://211.167.248.3/ccm/eintroccmreform.pdf.

44. China Global Fund CCM, Terms of Reference China Country Coordination Mechanism for the Global Fund to Fight AIDS, Tuberculosis and Malaria Project (Trial), http://211.167.248.3/ccm/ccmtor_en.pdf.

45. The texts containing these criticisms as well as the main documents in Chinese concerning CCM reform are available on the Aizhixing website: http://www.aizhi.net index.asp?action=Special $\&$ SpeciallD $=3$.

46. See for example Nick Young and Tina Qian, "Governance spat plagues coordinating board of Global Fund, divides NG0s," China Development Brief, 31 May 2006 http://www.chinadevelopmentbrief.com/node/631.

47. Young and Qian. Ibid. 
ences on this very issue. ${ }^{(48)}$ The two are now rivals. Rejecting all collaboration with the government and thus with the Global Fund as well, Wan later organised a counter-election, which was, however, rejected by the Fund, citing the absence of neutral outside observers.

Jia, for his part, initiated an ambitious process of revising the election validated by international experts, this time under the Fund's aegis. In order to reach out to the largest number of organisations, he called a large-scale consultation meeting of representatives from community-based associations. It was attended by some 150 civil society representatives, mostly from organisations lacking official registration. The meeting was a milestone in the anti-HIV/AIDS fight in China, not only because of the number of organisations present that lacked official papers, but also as it marked the emergence of HIV carriers' own demands.

\section{Appropriation of demands}

The emergence of this demand was symbolised by an improvised "zap" by a participant, the HIV-positive activist Meng Lin. This method, favoured by some associations in the West such as Act Up-Paris, consists of staging a surprise public event, such as during a meeting, in order to draw attention to a problem through a key personality. Meng staged a surprise at the meeting during the closing ceremony when he was quickly joined by the HIV carriers present and vehemently protested the lack of consideration for their views. There followed personal accounts by HIV carriers, many in tears, and complaints against other civil society members, who were accused of enriching themselves on the backs of those who only sought bare survival. They then complained about access to second-line treatment, their protest targeting the whole ruling class. Their tone and the symbolic violence in the often threatening language used and the emotion-charged invoking of deaths from the epidemic were reminiscent of the well-publicised activities of Act-up Paris. However, not all participants at the meeting saw the event as a replication of militant methods from democratic countries. Representatives of non-HIV-positive NGOs, who were the butt of some of the criticisms, saw the demonstration as showing a lack of maturity (chengshu) and culture (wenhua) and above all of awareness of the international development process and concepts linked to democracy, with which they felt better endowed. ${ }^{(49)}$ Moreover, if the "zap" effort had any publicity ambitions, there was little evidence of success: there was no media presence, and organisers almost immediately evacuated the rest of the audience from the hall.
The HIV carriers' lack of familiarity with civil society concepts is a problem they recognise and identify with lack of "culture." During the election campaign for new community representatives that followed the meeting, there was much discussion of the criteria to be followed for choosing them. It focused on whether it was better to choose a person adept at democratic rhetoric or someone identified as being closer to the mass of HIV carriers. While eschewing the kind of frontal attack that Wan had launched, most of the discontent was targeted at Cai's election as the HIV carriers' representative. Enquiries among HIV carriers in Beijing showed that he enjoyed far from unanimous backing. HIV carriers saw his actions as being attuned to the foreign media. Thus, his facility with English and access to friends from his long stay abroad were held against him. This seemed symptomatic of the growing influence of militant HIV carriers in Beijing, who were present in strength in the association.

Besides, they were hardly unanimous in their demands. For instance, Li Xiang voluntarily withdrew despite his massive popularity, because he did not favour HIV carriers descending on the political scene. ${ }^{\left({ }^{(5)}\right)} \mathrm{He}$ felt such an undertaking threatened to provoke the Chinese ideological and cultural system, and would also be inadequate, given the perception of HIV-positive people and their limited acceptance in society. The best course would be to keep a "low profile" (didiao), more in conformity with local practice and "Confucian thought." Further, like many others who favoured a "low profile," Li pointed to the negative effects of rivalry among associations and to their manipulation by others.

Paradoxically, this was also the argument of HIV carriers favouring the elections: an end to being manipulated by HIVnegative actors. Thus, during the pre-election campaign a Henan candidate enjoying Wan's backing publicised a certificate proving his HIV-positive status in order to dispel any doubts and legitimise his standing. Other HIV carriers asked about Li's decision to keep away from the process, linking his strategy with the manner by which he was infected, which sheltered him from much of the stigma other HIV populations faced, and which afforded him greater hope of integration with society. This view was notably formulated by the MSM group, although they rarely affirmed their homosexuality as legitimising their engagement, and continued to project themselves as victims alongside those who suffered from blood contamination in Henan. ${ }^{(51)}$ In general, most activists based the legitimacy of their own demands on the cause of the victims

48. Interviews.

49. Interviews.

50. Interviews. 
of contaminated blood. They were always well represented during meetings in Beijing of different categories of HIV carriers. While they spoke in halting Putonghua and peasant accents, which often became the butt of jokes, their interventions were always heard with respect, and were sometimes referenced or taken up by other activists more adept at expressing themselves. Similarly when more "urban" activists were invited to larger-scale meetings to represent HIV carriers among NGOs and international agencies, they were heard with the same solemn respect and often similar condescension with regard to their comprehension of the international development issues they referenced in describing their struggle.

Their discussions contain systematic mention of the death of near and dear ones due to HIV/AIDS and the epidemic's symbolic violence. Such talk helps unify the HIV carrier community, setting aside their divergences and their disparities in terms of legitimacy. The election campaign, mostly via the Internet, also showed the recurrence of nationalist arguments. Legitimacy is affirmed through their identification as both HIV carriers and Chinese. The central government's "harmonious society" (goujian hexie shehui) theme was taken up, especially during the political "freeze" that followed the Tibetan protests in early 2008 and preceded the Beijing Olympics. ${ }^{(52)}$ Such rhetoric, which can be interpreted as merely seeking to stave off repression, also reflects the fact that the middle class, which clearly backs the current regime, is represented in strength among the staff of international and local NGOs. Thus, Chinese anti-AIDS activists have been revising their systematic opposition to the government, which was symptomatic of a period when any action was unthinkable. And they have been consciously shaking off international influences. For instance, Meng, the MSM activist who was elected as an HIV carrier representative on the Global Fund, once compared "capacity building" in the HIV/AIDS fight to China's resistance against Japanese invaders. ${ }^{(3)}$ With a view to helping HIV carriers realise the utility of their engagement, they evoke the image of peasants who helped Chinese troops take on the Japanese through whatever means they could and through their knowledge of the terrain. A "therapeutic citizenship" is thus emerging. ${ }^{(54)}$

Chinese HIV carriers' original forms of engagement are evident in the anti-HIV/AIDS fight: their own demands are gradually taking shape. This takes undeniably globalising forms, as shown by the appropriation of the field by MSM from the major cities. The structural and ideological constraints frustrating the development of civil society and NGOs hinders a meaningful unity among the community of actors implicated and their respective struggles. However, the authorities' systematic opposition on the one hand, and the blind adherence to Western democratic precepts on the other, hardly augurs well for unanimity among HIV carriers who seek new ways of articulation and learning the art of the possible at the local level. Thus, talk of the legitimacy of HIV-positive individuals varies depending on the interlocutor, the participatory imperatives of international aid that funds initiatives, the government's ideological and structural straitjackets, and the differing demands that underlie and belie the Chinese HIV community's pluralism. However perilous, this political exercise seems possible today through the leitmotiv of access to medicine and the realisation of promises made in the central authorities' framework of engagement. $\bullet$

\section{- Translated by N. Jayaram}

\begin{tabular}{|c|c|}
\hline \multicolumn{2}{|l|}{ Glossary } \\
\hline Aizibing cun & 艾滋病村 \\
\hline Tongzhi & 同志 \\
\hline Caogen zuzhi & 草根組織 \\
\hline Shequ zuzhi & 社區組織 \\
\hline Zhuanjia & 専家 \\
\hline Yangguang yisheng & 陽光醫生 \\
\hline Aixin jiayuan & 愛心家園 \\
\hline Yonggan & 勇敢 \\
\hline Yingyong & 英勇 \\
\hline Ai zhi guanhai & 愛之關懷 \\
\hline Wei waiguoren fuwu & 為外國人服務 \\
\hline Chengshu & 成熟 ～～～～～～～～ \\
\hline Wenhua & 文化 \\
\hline Didiao & 低調 ～～～～～～～～～ \\
\hline Goujian hexie shehui & 構建和諧社會 \\
\hline \multicolumn{2}{|c|}{$\begin{array}{l}\text { Cunzai yu huangmiu: zhongguo dixia "xingchanye" kaocha } \\
\text { 存在與換繆:中國地下《性產業》考察 }\end{array}$} \\
\hline Si mian yi guanhuai & 四免一關懷 \\
\hline \multicolumn{2}{|c|}{$\begin{array}{l}\text { Zhongguo renmin daxue xing shehuixue } \\
\text { 中國人民大學性社會學 }\end{array}$} \\
\hline \multicolumn{2}{|c|}{$\begin{array}{l}\text { Henan aizibing wunian diaocha baogao } \\
\text { 河南愛滋病五年調查報告 }\end{array}$} \\
\hline
\end{tabular}

51. For the Henan HIV carriers' views on the use of their "suffering" by the capital's activists and journalists, see Shao Jing, "Fluid Labor and Blood Money: The Economy of HIV/AIDS in Rural Central China," Cultural Anthropology, Vol. 21-4, 2006, pp. 535-569.

52. On the "harmonious society" concept in the Olympic Games context, see Xin Xu, "Modernizing China in the Olympic Spotlight: China's National Identity and the 2008 Beijing Olympiad," Sociological Review, p.54-2, 2008, pp. 90-107, http://weblamp.princeton.edu/phcwp/pdfs/xu_xin_modernizing_china_in_olympic_spo tlight_2006.pdf.

53. Field notes, April 2008

54. Nguyen Vinh-Kim, "Antiretroviral Globalism, Biopolitics and Therapeutic Citizenship," International Development Research Center, 2004, http://www.idrc.ca/uploads/user/11176384921Antiretroviral_Globalism,_Biopolitics,_and_Therapeutic_Citizenship_.pdf. 